\title{
ANTIMICROBIAL ACTIVITY OF RED FRUIT (Pandanus Conoideus Lamk) PASTE AGAINST STAPHYLOCOCCUS AUREUS AND ESCHERICHIA COLI IN BURGER PATTIES
}

\author{
Selvia Tharukliling ${ }^{1)}$, Lilik Eka Radiati*2), Imam Thohari ${ }^{2)}$, Agus Susilo ${ }^{2)}$ \\ 1) Postgraduate Program, Faculty of Animal Science, Universitas Brawijaya, J1. Veteran Malang, 65145, \\ Indonesia \\ 2) Faculty of Animal Science, Universitas Brawijaya, J1. Veteran Malang, 65145, Indonesia \\ *Corresponding Email: lilik.eka@ub.ac.id
}

Submitted 19 January 2021; Accepted 3 May 2021

\begin{abstract}
This study aims to determine the antimicrobial activity of red fruit paste against Staphylococcus aureus FNCC-0047 and Eschericia coli FNCC-0091 by using ethanol and nhexane as well as the total plate count value of the patty with red fruit paste added on different observations day. The concentration of paste extract for antimicrobial activity test was $6.25 \%$, $12.5 \%, 25 \%, 50 \%$. The calculation of the total value of the burger patty plate is calculated on the $3^{\text {rd }}, 7^{\text {th }}$ and $14^{\text {th }} \mathrm{d}$ with the red fruit paste content in the formula as much as $0 \%, 5 \%, 10 \%$, $15 \%$. The results showed that the fatty acids of red fruit paste were dominated by oleic acid and linoleic acid, which are unsaturated fatty acids and palmitic acid, which are saturated fatty acids. The yield of red fruit paste in n-hexane solvent was higher than ethanol solvent. There was a significant difference $(\mathrm{P}<0.05)$ from the use of different solvents to the mean clear zone of the two bacteria tested. The antibacterial activity shown by the ethanol extract and n-hexane extract of red fruit paste was in the inactive category at the $6.12 \%$ level, the moderate category at the $12.5 \%$ to $25 \%$ level and the strong category at the $50 \%$ level. There was a significant difference $(\mathrm{P}<0.05)$ from the total microbial value in each treatment where the higher the red fruit paste content in the patty, the lower the total microbial value found on each $\mathrm{d}$ of observation. The use of red fruit paste at a level of $10 \%$ to $15 \%$ can withstand the rate of microbial growth.
\end{abstract}

Key words: Clear zone; fatty acids; patty; total microbes; yield 


\section{INTRODUCTION}

Antimicrobials are substances that can kill or inhibit the growth of microorganisms that are harmful to humans. Based on its ability, antimicrobials are divided into two, namely bacteriostatic which inhibits microbial growth and bactericidal which kills microbes. Antimicrobial compounds can be obtained from various parts of the plant from the tubers, stems, bark, leaves, rhizomes and seeds.

These compounds can be phenolic and terpenoid groups (Radiati, 2002). Red fruit (pandanus conoidus Lamk) plants are endemic plants that are widely grown in Papua Province, this plant is very adaptive and full of bioactive components (Budi, 2003). Red fruit is included in the pandanus genus, in the world There are around 700 species of pandanus around the world, which are distributed in tropical and subtropical regions. (Tan et al., 2010; Raj et al., 2014; Aforabi et al., 2019). Bioactive compounds that are mostly contained in red fruit are carotene compounds such as lutein, $\beta$-carotene, $\alpha$-carotene, $\quad \gamma$-carotene, zeaxanthin, lycopene, prolycopene, $\alpha$ kriptoxanthin, cantaxhantin, trans-lycopene and 4-keto-y- carotene, as well as tocoferol and fatty acids (Truly et al., 2009; Murtiningrum et al., 2012; Rochman et al., 2012).

The phytochemical content of the positive red fruit ethanol extract contains pheniolics, flavonoids, steroids, triterpenoids, saponins, tannins, alkaloids and hexane extracts that are positive for steroids and triterpenoids (Lisda et al., 2019). The hexane extract of red fruit oil contains $17.48 \%$ palmitic fatty acid, $79.53 \%$ oleic acid and $1.56 \%$ linoleic acid (Arumsari et al., 2013). Red fruit plants can inhibit the growth of pathogenic bacteria as reported by Indrawati (2016) that the ethanol extract of red fruit can inhibit $S$. aureus and $K$. pneumoniae while hexane extract inhibits $E$. Coli and B. Cereus. Damayanti et al. (2019) added that the red fruit extract showed antibacterial activity against oral bacteria $E$. faecalis, S. mutans, and $S$. sanguinis. According to Naiola (1999) fatty acids and glycerol esters are materials that are commonly used as antimicrobials, the results of chemical synthesis between fatty acids (caproic, caprylic, capric, lauric, myristic and palmitic) with ascorbic acid (vitamin C) show results that ascorbyl caprate has the highest antimicrobial activity shown by ascorbyl caprate, Ascorbyl caprate besides having fungistatic activity also has antimicrobial activity. Kumalasari et al. (2014) stated that 9,12octadecadienoic acid (linoleic acid), hexanoic acid (palmitic acid), and dodecanoic acid (lauric acid) were the result of hydrolysis of Chlorella sp. oil is a compound that actively inhibits $S$. aureus bacteria. Murhadi (2009) reported that fatty acids such as myristoleic, palmitoleic, linolenic, capric, lauric and myristic were shown to have antibacterial activity in $\mathrm{S}$. aureus bacteria.

Fatty acids can also help improve the quality of restructured meats into functional foods, such as the research of Muguerza $e t$ al. (2004) on increasing the nutritional value and functionality of dried foods through the addition of fish oil extracts which are rich in n-3 fatty acids. Restructured meat is very susceptible to contamination with microbes, one of which is because restructured meat is
*Corresponding author:

Lilik Eka Radiati

Email: lilik.eka@ub.ac.id

Faculty of Animal Science, Universitas Brawijaya,

Jl. Veteran Malang, 65145, Indonesia
How to cite:

Tharukliling, S., Radiati, L. E., Thohari, I., \& Susilo, A. (2021). Antimicrobial Activity of Red Fruit (Pandanus conoideus Lamk) Paste against Staphylococcus aureus and Escherichia coli in Burger Patties. Jurnal Ilmu dan Teknologi Hasil Ternak (JITEK), 16 (2), 132-143 
formed from chopped meat with a large surface and the water holding capacity is lower than whole meat, this causes bacteria to develop more easily.

Food from livestock is an excellent medium for the proliferation of pathogenic microbes such as Salmonella sp., Escherichia coli, Coliform, Staphylococcus sp. and Pseudomonas (Gustiani, 2009). Staphylococcus aureus and Eschericia coli bacteria are pathogenic bacteria that often contaminate various restructured meat products. Symptoms of disease caused by $E$. coli include cramps and diarrhea, urinary tract infections, pneumonia, bacterernia, neonatal meningitis, and cholangitis (Le loir et al., 2003, Putri, 2013). Staphylococcus aureus is one of the bacteria that causes foodborne disease which can cause food damage and poisoning (BPOM, 2012). The presence of bacteria in restructured meat such as patty will affect the shelf life and nutritional value of the product.

The utilization of red fruit oil has been widely researched both in vivo and in vitro, from the processing of red fruit oil it produces waste in the form of red fruit paste. No research has been done on the potential of red fruit paste as an antimicrobial agent, especially on the microbial pathogen contaminants of restructured meat products and its effect on the total value of the plate count patty with added red fruit paste. The aim of this research was to test the ability of the activity of the red fruit paste antimicrobial compound against Staphylococcus aureus and Escherichia coli by using ethanol and n-hexane solvents and its effect on the total plate count value if red fruit paste was added to the patty formula by observing $\mathrm{d} 3^{\text {rd }}, \mathrm{d} 7^{\text {th }}$ and $d 14^{\text {th }}$.

It is hoped that this research will become a preliminary study that can provide the latest information on the potential of red fruit paste as a natural antimicrobial source, especially in pathogenic bacteria contaminating livestock food products so that it can increase the economic value of red fruit paste which has been considered waste.

\section{MATERIALS AND METHODS}

\section{Making red fruit paste (RFP) using the wet rendering method}

This activity was carried out to make the basic material for research namely red fruit paste. The red fruit is washed first and then separated the pith and pulp, the pulp which will be processed into red fruit paste by going through 2 boiling stages. the first stage of the red flesh is boiled using a 1:2 water ratios (Murtiningrum et al., 2005, modification of boiling time) Red fruit flesh is boiled until boiling for $30 \mathrm{~min}$ and retained its boiling point for $20 \mathrm{~min}$, the stew is filtered to separate the seeds from the red fruit pulp.

After that, boil it again for $30 \mathrm{~min}$ to separate the oil and paste. The red fruit oil will sit on the surface by itself and the paste will settle to the bottom. The oil is taken using a spoon until it runs out until it is pressed to make sure the oil and paste are completely separated, then the paste is in a centrifuge for $10 \mathrm{~min}$ at a speed of $3000 \mathrm{rpm}$. The resulting pasta was analyzed qualitatively for the types of fatty acids using gas chromatography.

\section{Fatty Acids of Red Fruit Paste Profile}

The Shimadzu brand gas chromatography (GC) is used for fatty acid analysis (AOAC, 2005). Extraction of fatty acids with shocklet extraction, the formation of methyl ester (methylation) by weighing $30 \mathrm{mg}$ of paste fat, $0.5 \mathrm{~N} \mathrm{NaOH}$ in methanol and heated for $20 \mathrm{~min}$ in a water bath as much as $2 \mathrm{~mL}, \mathrm{BF}_{3}-\mathrm{CH}_{3} \mathrm{OH} 20 \%$, after that it is cooled and Add $2 \mathrm{~mL}$ of saturated $\mathrm{NaCl}$ and $1 \mathrm{~mL}$ of hexane then shake until homogeneous.

The hexane layer was transferred by pipette to a tube containing $0.1 \mathrm{~g}$ of anhydrous $\mathrm{Na}_{2} \mathrm{SO}_{4}$, left for $15 \mathrm{~min}$. The liquid phase is separated and then injected into GC. Identification of fatty acids is done by injecting methyl esters into a gas chromatograph. The standard fatty acid used was SupelcoTM 37 component FAME Mix. 


\section{Ethanol and n-Hexane Extraction}

Red fruit paste made by wet rendering (Murtiningrum et al., 2012, modification of boiling time) is macerated extracted with two solvents, $96 \%$ ethanol and n-hexane, the maceration time is $3 \times 24 \mathrm{~h}$ with stirring using stirred each. $6 \mathrm{~h}$ for $5 \mathrm{~min}$. extract mixed with solvent filtered using Whatmann filter paper. The results of the filtration in the first $24 \mathrm{~h}$ are collected (filtrate I) of the dregs of filtrate 1 then a new solvent is added by working like at the beginning of maceration so that the results of filtrate II and filtrate III are obtained. Three of filtrate obtained are combined into one then filtered again with Whatmann paper number 1 . Then the filtrate is evaporated using a rotary evapotaror (temperature $30^{\circ} \mathrm{C}$, pressure $200 \mathrm{mBar}, 25 \mathrm{rpm}$ rotation). DMSO $10 \mu \mathrm{L}$ was added to the concentrated extract of each solvent as a diluent and then tested for antimicrobial activity by the disc diffusion method. The extract concentrations used as treatment were $6.25 \%, 12.5 \%, 25 \%$ and
$50 \%$. negative control is DMSO. The types of microbes tested were gram-positive Staphylococcus aureus FNCC-0047 and gram-negative Escherichia coli FNCC0091. The parameters observed were the yield of the extract and the clear zone as an indicator of antimicrobial inhibition which was measured using a caliper with units of $\mathrm{mm}$. The ability of the antibacterial activity of red fruit paste from ethanol and n-hexane solvents was determined based on the classification of antibacterial activity according to Surjowardjoyo et al. (2015).

\section{Extract yield}

The yield is the ratio between the extract obtained and the initial simplicia. The yield uses percent (\%) units, the higher the yield value is, the more the extract value is produced. The yield of an extract can be influenced by several factors, one of which is the extraction method used (Hasnaeni et al., 2019) The yield of ethanol and n-hexane extract was calculated using the formula:

$$
\% \text { yield }=\frac{\text { Extract weight }(\text { gram }) \times 100 \%}{\text { The weight of the simplicia before extract }}
$$

\section{Total Plate Count (TPC)}

The red fruit paste (RFP) levels used in the patty formula were R0 $(0 \%), \mathrm{R} 1(5 \%$ RFP), R2 (10\% RFP) and R3 (15\% RFP). The procedure for determining TPC (SNI 01-2332.3-2006) was by weighing $25 \mathrm{~g}$ of the sample aseptically and then placing it in a sterile plastic container.

About $225 \mathrm{~mL}$ of phosphate buffer solution was added and homogenized using a Stomacher for $2 \mathrm{~min}\left(10^{-1}\right.$ dilution solution using a sterile pipette, $1 \mathrm{~mL}$ of the homogenate was taken and put in a tube containing $9 \mathrm{~mL}$ of phosphate buffer solution to get a $10^{-2}$ dilution. Each dilution was subjected to shaking of at least $25 \mathrm{~s}$, so the same was done in the next dilution according to the sample conditions. Total plate count was determined using the following equation:

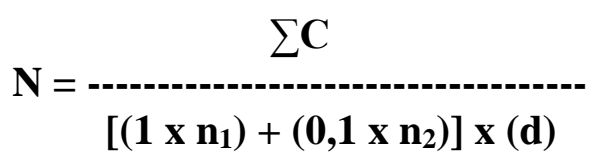

Note:

$\mathrm{N} \quad$ : the number of product colonies, expressed in colonies per $\mathrm{ml}$ or colonies per gram

$\Sigma \mathrm{C} \quad:$ the number of colonies on all the plates counted

n1 : the number of plates at the first dilution counted

n2 : the number of plates at the second dilution counted

d : the first dilution calculated 


\section{Statistical Analysis}

Data were analyzed using analysis of variance (ANOVA) to determine the effect of level of paste extracts with different solvents on pathogenic bacteria and to determine the effect of red fruit paste level in the patty formula on the value of the total plate count in patty. When there was a significant difference, it would be followed by Duncan's test.

\section{RESULTS AND DISCUSSION}

\section{Profile Fatty Acids of Red Fruit Paste}

Based on Figure 1, the results of the detector readings on the GC tool have recorded a peak sequence representing one compound in the mixture passing through the detector with different retention times in each sample component.

Each peak and area of the chromatogram produced were used as a quantitative analysis of the sample. The following is a graph of the fatty acid chromatogram on red fruit paste. Based on the detected graph, the highest peak of retention min 12.33 was confirmed to be C18:1n9 compound (oleic acid), then the second highest peak in retention min 9.87 was C16:0 (palmitic acid) and the third peak in retention $\min 12.83$ is $\mathrm{C} 18: 2 \mathrm{n} 3$ (linoleic acid). The following is the fatty acid profile of red fruit paste using the GC test method as follows:

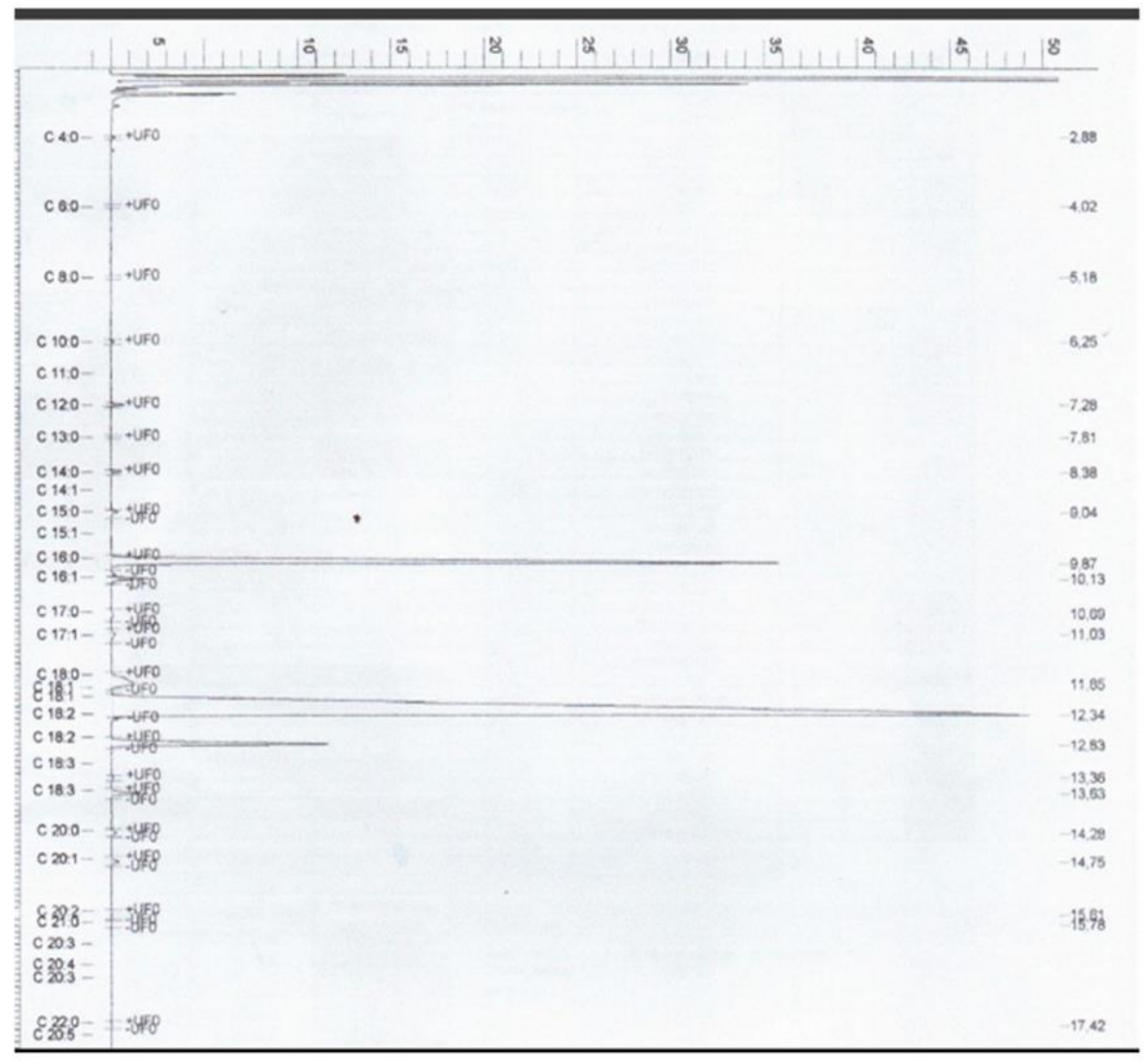

Figure 1. Chromatogram of the fatty acids of red fruit paste 
Table 1. Fatty acids profile of red fruit paste by gas chromatography

\begin{tabular}{|c|c|c|c|c|}
\hline No & Fatty acids & $\begin{array}{l}\% \text { fatty acid in } \\
30 \mathrm{mg} \text { sample }\end{array}$ & $\begin{array}{l}\% \text { Total fatty } \\
\text { acid }\end{array}$ & $\begin{array}{l}\text { Retention Time } \\
\text { (min) }\end{array}$ \\
\hline \multirow[t]{11}{*}{1} & Saturated Fatty Acids (SFA) & & & \\
\hline & C 20:0 (arachidic acid) & 0.01 & & 14.26 \\
\hline & C 10:0 (capyric acid) & 0.00 & & 6.24 \\
\hline & C 18:0 (stearic acid) & 0.21 & & 11.84 \\
\hline & C 12:0 (lauric acid) & 0.02 & & 7.27 \\
\hline & C 24:0 (lignoceric acid) & 0.00 & & 20.99 \\
\hline & C 14:0 (myristic acid) & 0.02 & & 8.38 \\
\hline & C 15:0 (pentadecanoic acid) & 0.02 & & 9.03 \\
\hline & C 16:0 (palmitic acid) & 2.63 & & 9.87 \\
\hline & C 17:0 (heptadecanoic acid) & 0.01 & & 10.69 \\
\hline & Total SFA & 2.92 & 22.27 & \\
\hline \multirow[t]{6}{*}{2} & $\begin{array}{l}\text { Monounsaturated fatty acids } \\
\text { (MUFA) }\end{array}$ & & & 14.75 \\
\hline & C 20:1 (eicosenoic acid) & 0.02 & & 10.12 \\
\hline & C 16:1 (palmitoleic acid) & 0.08 & & 11.02 \\
\hline & C 17:1 (heptadecenoic acid) & 0.02 & & 12.33 \\
\hline & C $18: 1 n 9 C$ (c-oleic acid) & 9.24 & & \\
\hline & Total MUFA & 9.36 & 71.14 & \\
\hline \multirow[t]{2}{*}{3} & $\begin{array}{l}\text { Polyunsaturated fatty } \text { acids } \\
\text { (PUFA) }\end{array}$ & 0.78 & & 12.83 \\
\hline & $\begin{array}{l}\text { C 18:2n3 (linoleic acid) } \\
\text { C 20:2 (eicosadienoic acid) }\end{array}$ & 0.00 & & 15.61 \\
\hline
\end{tabular}

Total MUFA

Based on Table 1, the dominant fatty acids in the red fruit paste, if sorted into the three highest percentages are oleic acid $9.24 \%$, palmitic acid $2.63 \%$ and linoleic acid $0.78 \%$. Palmitic acid is a saturated fatty acid while oleic and linoleic acids are unsaturated fatty acids, when compared with the fatty acid content of commercial red fruit oil according to Sarongallo et al. (2014), the percentage value of oleic acid, palmitic acid and linoleic acid is significantly reduced in red fruit paste. This happens because the red fruit paste is the byproduct of processing the red fruit into oil so that most of the fatty acids are more soluble in oil and only a little left in the paste. Kumalasari et al. (2014) stated that linoleic acid, hexanoic acid palmitic acid, and lauric acid were the result of hydrolysis of Chlorella $\mathrm{sp}$ oil is a compound that actively inhibits $S$. aureus bacteria.

$0.78 \quad 6.59$

\section{The yield of ethanol extract and n- hexane red fruit paste}

Based on Table 2, It shows that the yield of n-hexane solvent is higher compared to ethanol solvent. The higher yield value that is produced, the more extract value is produced.

The yield value is used to determine the effectiveness of the economic value of a product or material. The higher the yield, the higher the economic value of the product. In this study, the type of solvent affected the size of the yield value of red fruit paste. The n-hexane solvent had a yield value of $14.61 \%$ and $4 \%$ lower yield of ethanol, which was $10.61 \%$.

According to Murtiningrum et al. (2005), the effect of the freshness of the ingredients, species and handling methods had a significant effect on the yield of red fruit oil. 
Table 2. The yield value of red fruit paste

\begin{tabular}{lcccc}
\hline Solvent & Amount of paste $(\mathrm{g})$ & Amount of solvent $(\mathrm{mL})$ & Yield $(\%)$ & Color \\
\hline Ethanol & 50 & 500 & 10.61 & red \\
n-hexane & 50 & 500 & 14.61 & deep red \\
\hline
\end{tabular}

Based on Table 3, it shows the highest inhibition zone values for Escherichia coli bacteria in the ethanol + DMSO $50 \%$ treatment level of $11.90 \pm 5.06$, and the lowest average number of inhibition zones for $E$. coli bacteria in the DMSO treatment $(-)$ is $0.00 \pm 0.00$.

The results of the analysis show that the mean number of inhibition zone for Escherichia coli bacteria between Ethanol and n-hexane solvent there is no significant different, it can be seen from the quite large standard deviation in each treatment. Determination of the concentration of red fruit paste extract affects the formation of the inhibition zone of the tested bacteria.
The lower the concentration, the less active substance dissolved from the red fruit paste extract.

The difference in the solvent used affects the type of bioactive dissolved in the extract such as ethanol solvent will dissolve all polar bioactive components of the red fruit paste and the n-hexane solvent will dissolve all non-polar bioactive compounds. According to Surjowardjoyo et al. (2015) the antimicrobial activity of red fruit paste extract from both solvents is inactive category for the extract level of $6.25 \%$, the moderate category for the extract level of $12.5 \%$ to $25 \%$ and the strong category for the $50 \%$ level.

Table 3. Mean of inhibition zone ( $\varnothing \mathrm{mm})$ to the test microbes of Escherichia coli

\begin{tabular}{lcccc}
\hline Treatment & \multicolumn{4}{c}{ Level of red fruit paste } \\
\cline { 2 - 5 } & $6.25 \%$ & $12.5 \%$ & $25 \%$ & $50 \%$ \\
\hline Etanol + DMSO & $3.50 \pm 6.06^{\mathrm{a}}$ & $7.40 \pm 6.48^{\mathrm{b}}$ & $7.43 \pm 6.78^{\mathrm{b}}$ & $11.90 \pm 5.05^{\mathrm{c}}$ \\
Hexane + DMSO & $3.40 \pm 5.88^{\mathrm{a}}$ & $7.90 \pm 5.58^{\mathrm{b}}$ & $7.60 \pm 4.19^{\mathrm{b}}$ & $11.66 \pm 7.15^{\mathrm{c}}$ \\
DMSO (-) & 0 & 0 & 0 & 0 \\
\hline
\end{tabular}

Note: Numbers followed by different superscripts in the same row mean significantly different at the Duncan test level of $5 \%(\mathrm{P}<0.05)$.

Based on Table 4, the results of the one-way ANOVA test, there is a significant difference in the average inhibition zone values for Staphylococcus aureus bacteria between treatments.

In the notation column, the results show that the highest average inhibition zone number of Staphylococcus aureus bacteria in the hexane + DMSO treatment level is $50 \%$, hexane DMSO level is $25 \%$ and Ethanol + DMSO level is $50 \%$ significantly different from the treatment. The lowest average number of Staphylococcus aureus bacteria inhibition zones in the DMSO (-) treatment was significantly lower than other treatments.

Table 4. Mean of inhibition zone $(\varnothing \mathrm{mm})$ to the test microbes of Staphylococcus aureus bacteria

\begin{tabular}{lcccc}
\hline Treatment & \multicolumn{4}{c}{ Level of red fruit paste } \\
\cline { 2 - 5 } & $6.25 \%$ & $12.5 \%$ & $25 \%$ & $50 \%$ \\
\hline Etanol + DMSO & $2.67 \pm 4.62^{\mathrm{a}}$ & $5.50 \pm 5.67^{\mathrm{b}}$ & $9.63 \pm 1.50^{\mathrm{c}}$ & $11.70 \pm 1.66^{\mathrm{d}}$ \\
Hexane + DMSO & $4.47 \pm 6.08^{\mathrm{a}}$ & $6.80 \pm 2.25^{\mathrm{b}}$ & $10.60 \pm 2.74^{\mathrm{c}}$ & $12.50 \pm 2.32^{\mathrm{d}}$ \\
DMSO (-) & 0 & 0 & 0 & 0 \\
\hline
\end{tabular}

Note: Numbers followed by different superscripts in the same row mean significantly different at the Duncan test level of $5 \%(\mathrm{P}<0.05)$. 
Determination of the concentration of the red fruit paste extract greatly affects the formation of the inhibition zone produced by the two test bacteria. The lower the concentration given, the smaller the diameter of the inhibition zone formed by the test bacteria, because the smaller the concentration, the less active substance dissolved from the red fruit paste extract. The difference in the solvent used affects the type of bioactive dissolved in the extract such as ethanol solvent which will dissolve all polar bioactive components of the red fruit paste and the n-hecane solvent will dissolve all non-polar bioactive compounds. According to Ida (2016), red fruit can inhibit the growth of pathogenic bacteria, ethanol extract inhibits $S$. aureus and $K$. pneumoniae and n-hexane extract can inhibit $E$. coli and B. cereus. Lisda et al. (2019) state red fruit ethanol extract positive contains phenolics, flavonoids, steroids, triterpenoids, saponins, tannins, alkaloids and hexane extracts that are positive for steroids and triterpenoids. According to Cowan (1999), terpenenes or terpenoids are active against bacteria, fungi, viruses and protozoa, terpenoids and steroids will damage the bacterial cell membrane and react with lipophilic compounds which result in leakage of liposomes and damage the porin so that the membrane becomes brittle and the bacteria lack nutrients until finally lysis.

In the observation of the inhibition zone against $E$. coli, there was no significant difference between the two solvents, but different things happened in the response of $S$. aureus bacteria to the two solvents, the extract from the n-hexane solvent, the inhibition zone value was significantly higher than the ethanol extract. This is because the basic content of red fruit plants which contain lots of potential fatty acids as antimicrobial and bioactive compounds dissolve in non-polar solvents such as nhexane, this is in accordance with the statement of Arumsari et al. (2013) that Hexane is the best solvent for used for the analysis of red fruit oil which was shown by the highest absorption coefficient of red fruit oil in both the hexane and chloroform fractions. In line with Kumalasari et al. (2014) stated that 9,12-octadecadienoic acid (linoleic acid), hexanoic acid (palmitic acid), and dodecanoic acid (lauric acid) were the result of hydrolysis of Chlorella sp. oil is a compound that actively inhibits $S$. aureus bacteria. Murhadi (2009) reported that fatty acids such as myristoleic, palmitoleic, linolenic, capric, lauric and myristic were shown to have antibacterial activity in $S$. aureus bacteria

The mechanism of the red fruit paste fatty acids in $n$-hexane extract against bacteria is to invade the cell membrane then damage the lipid wall which is a source of energy for bacteria so that it will interfere with the metabolic process so that antibacterial compounds can more easily enter bacterial cells and will causes inhibition of the biosynthesis of specific enzymes needed in a metabolic reaction and eventually the cell becomes lysis and eventually the bacteria will die. Staphylococcus aureus is gram-positive bacteria where this type of bacteria has a simpler cell wall than gram-negative bacteria. According to Hawley (2003) the structure of the gram-positive bacteria cell wall is simpler, namely layered with a low lipid approximately $1-4 \%$ so that makes it easier for bioactive materials to enter the cell while the structure of the gram-negative bacterial cell wall is more complex, three layers, namely the outer lipoprotein layer, the lipopolysaccharide middle layer which acts as a barrier to the entry of antibacterial bioactive materials and the inner layer is a peptidoglycan with high lipid approximately $11-12 \%$.

The ability of the antibacterial activity of the red fruit paste from ethanol and nhexane solvents from research results can be determined based on the classification according to Surjowardjoyo et al. (2015) the antibacterial activity shown by the ethanol extract and $n$-hexane extract of red fruit paste at the level of $6.25 \%$ is in the inactive category because the diameter range of the inhibition zone formed is only between 
$2.67 \mathrm{~mm}$. up to $4.47 \mathrm{~mm}$ in $E$ coli and $S$ aureus bacteria. whereas at the extract level of $12.6 \%$ to $25 \%$ both of solvents showed a moderate antibacterial activity category with a range of inhibition zone diameters from $5.50 \mathrm{~mm}$ up to $10.60 \mathrm{~mm}$. Level ekstrak etanol and hexane of 50\% showed a strong antibacterial activity category with a range of inhibition zone diameters from $11.66 \mathrm{~mm}$ up to $12.50 \mathrm{~mm}$ so this indicates that the antibacterial activity of red fruit paste is present and its ability to inhibit bacteria and will increase along with the increasing level of the red fruit paste extract in the solvent.

\section{Total Plate Count (TPC)}

The total microbe on the $3^{\text {rd }} \mathrm{d}$ based on the results of statistical tests, there was a significant difference (level of $\mathrm{P}<0.05$ ) between treatments on the $3^{\text {rd }} \mathrm{d}$ the average lowest TPC number on treatment R3 was significantly different from treatment $\mathrm{R} 0$, $\mathrm{R} 1$ and $\mathrm{R} 2$. The $7^{\text {th }}$ of total microbes based on statistical tests there was a significant difference (level $\mathrm{P}<0.05$ ) between treatments on the $7^{\text {th }} \mathrm{d}$ there was a change in value where R3 and R2 treatments were not significantly different but R3 and R2 were significantly different from R0 and R1. On the $14^{\text {th }}$ day, the total microbial results of the statistical test still showed a significant difference (level of $\mathrm{P}<0.05$ ) in the R3 and $\mathrm{R} 2$ treatments which were not significantly different but significantly different from the R0 and R1 treatments. The lowest total microbial value was at $\mathrm{R} 3$ and the highest at R0 as control treatment without red fruit paste and followed by R1 with 5\% red fruit paste and R2 with 10\% red fruit paste.

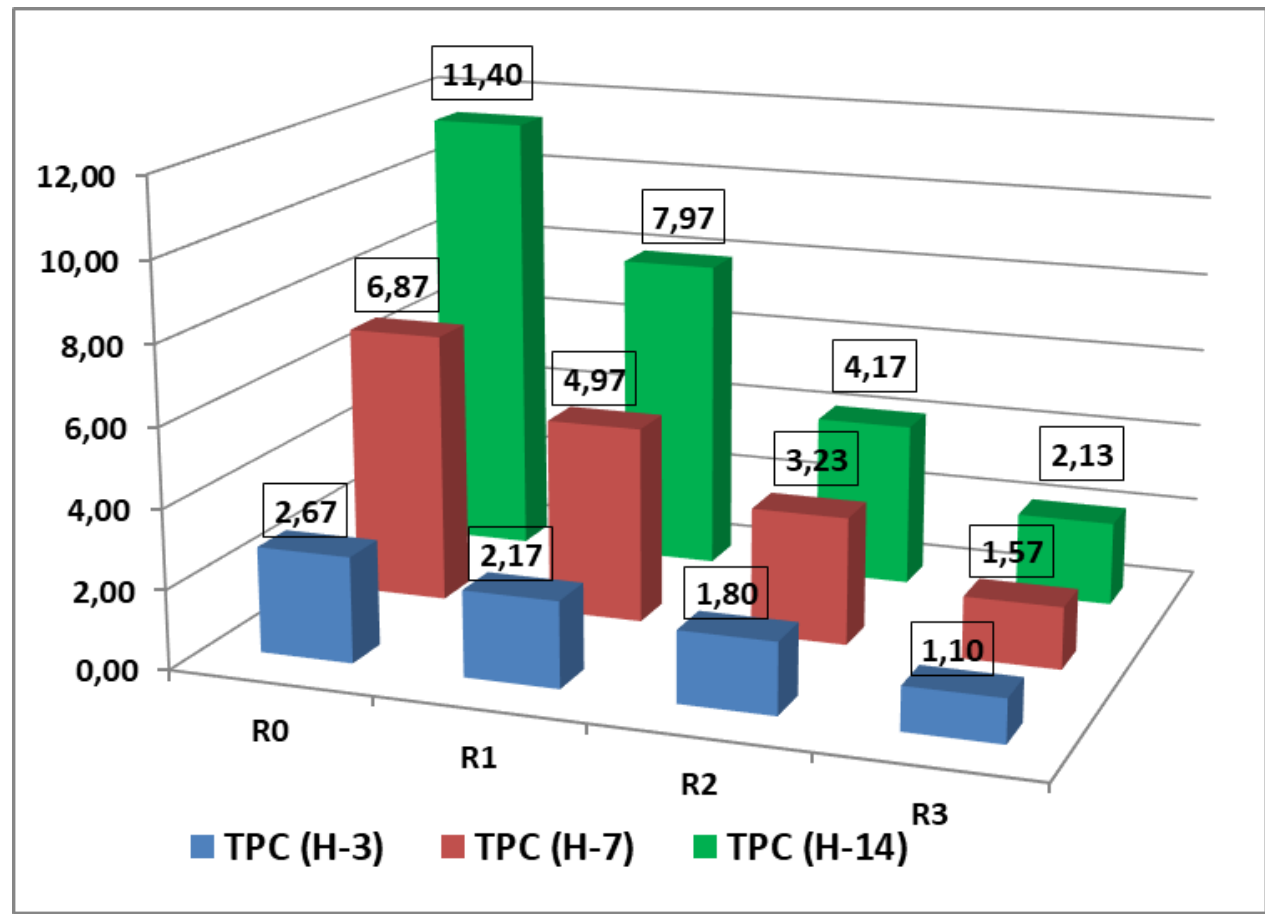

Figure 2. Total of microbes on 3rd, 7th and 14th d observation. R0 as control treatment (without red fruit paste/RFP), R1 with 5\% RFP, R2 with 10\% RFP and R3 with 15\% RFP.

Based on the graph of the TPC value, the total microbial value showed different results on the $3^{\text {rd } d}$ but the difference in values was increasingly changing on the $7^{\text {th }}$ and $14^{\text {th }}$ observation days. R3 treatment with $15 \%$ paste level on average resulted in the lowest total TPC value and R0 treatment at $0 \%$ level or without red fruit paste had the highest total TPC value at each observation time, this means that the level of red fruit paste in the dough burger patty is inversely related to microbial growth in burger patty. 
The higher the level of the paste, the lower the total microbial value, this is related to the activity of bioactive compounds and fatty acids in red fruit paste which function as natural antimicrobials and antioxidants such as tocopherols which can inhibit the oxidation process due to microbial growth in the patties. According to Murhadi (2009), several types of free fatty acids have been shown to have very strong antibacterial power, such as linoleic, arachidonic, linolenic, myristoleic, palmitoleic, linolenic, capric, lauric and myristic acids. Ascorbyl caprate, besides having fungistatic activity, also has antimicrobial activity.

Observations on $\mathrm{d}^{\text {th }}$ to $\mathrm{d} 14^{\text {th }}$ showed a high difference in the total number of microbes in treatment R0 (0\% RFP) and R1 (5\% RFP) but in treatment R2 (10\% RFP) and R3 (15\% RFP) the difference in total microbes is only a little, it can be assumed that the use of red fruit paste at a level of $10 \%$ to $15 \%$ can withstand the rate of microbial growth and can extend the shelf life of burger patties, which in this study do not use chemical preservatives until $14^{\text {th }}$ days. According to Abdulla et al. (2016) stated that microbial growth in meat and processed meat products can cause damage to sensory characteristics and is responsible for reducing nutritional value. According to the BPOM RI (2012), TPC is generally not related to food safety hazards but is sometimes useful to show quality, shelf life/half-life, contamination, and hygienic status during the production process.

\section{CONCLUSION}

In conclusion, the dominant red fruit paste fatty acids are oleic acid, palmitic acid and linoleic acid. The use of ethanol extract and n-hexane red fruit paste at different levels showed antimicrobial activity against Staphylococcus aureus FNCC-0047 and Eschericia coli FNCC-0091 bacteria. The higher the red fruit paste level in the patty dough was added, the lower the total microbial counts on all observation days were observed.

\section{REFERENCES}

Abdulla, G., Abdel-Shafi, M., Abdel, S., \& Dalia, Z. (2016). Evaluation of the antioxidant and antimicrobial effects of ziziphus leaves extract in sausage during cold storage. Pakistan Journal of Food Science, 26(1), 10-20.

Afolabi, L. O., Megat-Yusoff, P. S. M., Ariff, Z. M., \& Hamizol, M. S. (2019). Fabrication of pandanus tectorius (screw-pine) natural fiber using vacuum resin infusion for polymer composite application. Journal of Materials Research and Technology, 8(3), 3102-3113. https://doi.org/10.10 16/j.jmrt.2017.05.021

Arumsari, N., Sugeng, R., \& Abdul, R. (2013). Some physico-chemical properties of red fruit oil (Pandanus Conoideus Lam) from hexane and chloroform fractions. Journal of Food and Pharmaceutical Sciences, 1(2). https://doi.org/10.14499/jfps

Association Official Analitycal Chemistry. (2005). Official Method of Analysis (18th ed.). AOAC International.

BPOM RI. (2012). Pedoman Kriteria Cemaran pada Pangan Siap Saji dan Pangan Industry Rumah Tangga. Direktorat Standarisasi Produk Pangan deputi Bidang Pengawasan Keamanan Pangan dan Bahan Berbahaya Badan Pengawas Obat Dan Makanan Republik Indonesia.

Cowan, M. M. (1999). Plant products as antimicrobial agents. In Clinical Microbiology Reviews (Vol. 12, Issue 4). https://doi.org/10.1128/cmr.12.4.564

Damayanti, L., Evaangelina, I. A., Laviana, A., Herdiyati, Y., \& Kurnia, D. (2020). Antibacterial activity of buah merah (Pandanus conoideus Lam.) against bacterial oral pathogen of streptococcus sanguinis ATCC10556, streptococcus mutans ATCC 25175, and enterococcus faecalis ATCC 29212: An in Vitro Study. The Open Dentistry Journal, 14(1), 113-119. https://doi.org/10.2174/18742106020 
140113

Gustiani, E. (2009). Pengendalian cemaran mikroba pada bahan pangan asal ternak (daging dan susu) mulai dari peternakan sampai dihidangkan. Jurnal Litbang Pertanian, 28(3), 96-100.

Hasnaeni, H., Usman, S., \& Wisdawati, W. (2019). Pengaruh metode ekstraksi terhadap rendemen dan kadar fenolik ekstrak tanaman kayu beta-beta (Lunasia amara Blanco). Jurnal Farmasi Galenika (Galenika Journal of Pharmacy) (e-Journal), 5(2), 175182. https://doi.org/10.22487/j244287 44.2019.v5.i2.13599

Hawley, R. (2003). Enterotoxigenic Escheri-chia coli. http://vm.cfsan.fda. gov/mov/chap14.html

Indrawati, I. (2016). Sensitivity of Pathogenic Bacteria to Buah Merah (Pandanus conoideus Lam.). AIP Conference Proceedings, 020028-1020028-020029. https://doi.org/10.10 63/1.4953502

Kumalasari, D., Fasya, A. G., Adi, T. K., \& Maunatin, A. (2014). Uji aktivitas antibakteri asam lemak hasil hidrolisis minyak mikroalga Chlorella sp. ALCHEMY, 3(2), 163-172. https:// doi.org/10.18860/al.v0i1.2910

Loir, Y. L., Baron, F., \& Gautier, M. (2003). Staphylococcus aureus and food poisoning. laboratoire de microbiologie. Institut Nationale de La Recherche Agronomique, Fransce, 31(2), 63-76. https://doi.org/10.1111/ j.1574-6976.2011.00311.x

Muguerza, E., Ansorena, D., \& Astiasarán, I. (2004). Functional dry fermented sausages manufactured with high levels ofn-3 fatty acids: nutritional benefits and evaluation of oxidation. Journal of the Science of Food and Agriculture, 84(9), 1061-1068. https: //doi.org/10.1002/jsfa.1786

Murhadi. (2009). Senyawa dan aktivitas antimikroba golongan asam lemak dan esternya dari tanaman. Jurnal Teknologi Industri Dan Hasil Pertanian, 14(1), 97-105.
Murtiningrum. (2005). Ekstraksi minyak dengan metode wet rendering dari buah pandan (pandanus conoideus) dan pemurnian dengan filtrasi membran. Jurnal. Tek. Ind, 15(1), 28-33.

Murtiningrum, M., Sarungallo, Z. L., \& Mawikere, N. L. (2011). The exploration and diversity of red fruit (Pandanus conoideus L.) from Papua based on its physical characteristics and chemical composition. Biodiversitas Journal of Biological Diversity, 13(3), 1061-1068. https:// doi.org/10.13057/biodiv/d130304

Naiola, E. (1999). Karakterisasi aktivitas antimikroba beberapa asam lemak askorbil. Berita Biologi , 4(5), 305313. https://doi.org/10.14203/BERIT ABIOLOGI.V4I5.1249

Noor Anggita Putri, F., \& Krisna Wardani, A. (2015). The implementation of gamma irradiation technology and frozen storage for decreasing pathogens bacteria in seafood: a review. Jurnal Pangan Dan Agroindustri, 3(2), 345-352.

Radiati, E. (2002). Mekanisme Penghambatan Virulensi Bakteri Enteropatogen oleh Ekstrak Rimpang Jahe (Zingiber officinale Roscoe). Institut Pertanian Bogor.

Raj, G. G., Varghese, H. S., Kotagiri, S., Vrushabendra Swamy, B. M., Swamy, A., \& Pathan, R. K. (2014). Anticancer studies of aqueous extract of roots and leaves of pandanus odoratissimus f. ferreus (Y. Kimura) hatus: an in vitro approach. Journal of Traditional and Complementary Medicine, 4(4), 279-284. https://doi. org/10.4103/2225-4110.129199

Rohman, A., Riyanto, S., Yuniarti, N., Saputra, W., Utami, R., \& Mulatsih, W. (2010). Antioxidant activity, total phenolic, and total flavonoid of extracts and fractions of red fruit (Pandanus conoideus Lam). International Food Research Journal, 17(1), 97-106.

Sarungallo, Z. L., Hariyadi, P., \& 
Andarwulan, N. (2014). The effect of extraction method on the chemical quality and fatty acid composition of red fruit (Pandanus Conoideus) OIL. Jurnal Teknologi Industri Pertanian, 24(3), 209-217.

Surjowardojo, P., Susilawati, T., \& Sirait, G. (2015). Daya hambat dekok kulit apel manalagi (Malus sylvestrs Mill.) terhadap pertumbuhan staphylococcus aureus dan Pseudomonas sp. penyebab mastitis pada sapi perah. TERNAK TROPIKA Journal of Tropical Animal Production, 16(2), 40-48. https://doi.org/10.21776/ub.jta pro.2015.016.02.6

Tan, M. A., Kitajima, M., Kogure, N., Nonato, M. G., \& Takayama, H. (2010). Isolation and total syntheses of two new alkaloids, dubiusamines-A, and $-\mathrm{B}$, from Pandanus dubius. Tetrahedron, 66(18), 3353-3359. https: //doi.org/10.1016/j.tet.2010.02.073

Trully, M., Parinussa, S., \& Rondonuwu, F. (2009). Analisis kandungan karotenoid buah merah (Pandanus conoidus Lamk) pada suhu pemanasan yang berbeda. Seminar Nasional Kimia Dan Pendidikan Kimia, 473-486. 